\title{
Attaining Poverty Alleviation through Physiocratic Principles: Nigeria in Focus
}

\author{
Omonzejie, Peter I. ${ }^{2}$ Omonzejie, Eunice E. Ph.D \\ DepartmentofEconomics Ambrose Alli University PMB 14 Ekpoma, Nigeria \\ Department of Modern Languages Ambrose Alli UniversityPMB 14 Ekpoma, Nigeria
}

\begin{abstract}
Nigeria's overdependence on petroleum resource, kleptocracy and gross mismanagement of the oil wealth, are sapping the resilience of the nation's economy. Against the background of agricultural inequity, whatever the development strides taken by Nigeria over the decades, much remains to be achieved. Underscoring the direct and positive relationship between employment and poverty reduction, this paper sought to scrutinise the scope of agricultural activities in Nigeria as various poverty alleviation initiatives are set in motion by the Nigerian government in pursuance of the attainment of Africa's Millennium Development Goals. Of great significance in our research is the fact that the French economic doctrine of physiocracy advocates compliance with the "ordre naturel" and equitable use of land exploitation to maximise agricultural productivity and autonomous peasant participation. Our study is hinged on the premise that for the inclusive economic growth of Africa's most populous nation (with over $40 \%$ youth unemployment rate), physiocracy should be embraced, capitalising on its abundant land endowments as well as its teeming youth population. We have thus attempted in this paper to expose how physiocratic principles and practices should be integrated into poverty reduction strategies in Nigeria, in order to attain a more equitable participation of the masses in the agricultural sector. If this sector of the economy is appropriately developed, poverty will be considerably minimised and Nigeria will surely become an economic powerhouse.
\end{abstract}

Keywords: Physiocracy, poverty alleviation, agriculture, economic development, Nigeria,

\section{Introduction}

Though poverty is a relative term, there is a minimum benchmark for its measurement. The indisputable fact is that extreme poverty remains widespread in the developing world (Smith, 2005). The World Bank Poverty Reports (1998) show that about 1.2 billion people live on less than one dollar (\$1) per day at purchasing power parity and more than 2.8 billion people (almost half of the world population) live on less than two dollars (\$2) a day. Todaro and Smith (2005) equally explained the nature and extent of poverty to include under-nutrition and poor health. We must immediately stress that apart from providing food and raw materials for industrial purposes, agriculture has been and remains a veritable tool for providing employment for a large percentage of the population in most developing countries. All things being equal, an employed person is in a more positive position to address and find solution to his poverty state than the unemployed. Hence the role of agriculture which is the spinal column of physiocratic doctrine must be fully appreciated and exploited if sustainable development is to be achieved in any economy.

Impoverished people often suffer neglect and deprivations as such they are more likely to have little or no education, live in slums and environmentally degraded areas, political voicelessness, limited income if at all and very small farm lands. It must however be brought to fore that though this class of people in the society may appear to be voiceless, they pose a security threat to the society and the situation of development of the economy. Evidently, the rich in inequitable societies may well not have the freedom to enjoy their wealth to the fullest since the poor is susceptible to crime and most times the wealthy are inherently the victims of those crimes. So the truism ascribed to Adam Smith in 1776 underlines the social import of poverty as "no society can surely be flourishing and happy of which far the greater part of the numbers are poor and miserable".

It is no accident then that the eradication of poverty and hunger comes first on the agenda of Africa's Millennium Development Goals (MDGs). Nelson and Prescott (2003) attribute this to the fact that poverty exacerbates inequality and subsists as a central cause of conflict and insecurity. Tackling the issue of poverty has continued in recent times to take front stage in most economic policies of the Nigerian government. But the different programmes launched have failed to significantly improve the agricultural sector and to provide food security. It is on this premise we want to examine how the French physiocratic principles can effectively be integrated into poverty alleviation strategies in the country. The study thus seeks to explain the different ways in which the principles and practices of physiocracy could be advantageously brought to bear on the Nigerian economic scene with the aim to reducing poverty to its barest minimum. 
To effectively accomplish its objectives, this paper is structured into sections. Section two which follows this introduction is the literature review, theoretical framework, as well as physiocratic theory. Physiocracy in practice is discussed in Section three, while in section four we examine physiocratic policies and poverty alleviation in Nigeria. Finally, Section five presents the recommendations and conclusions.

\section{Literature Review}

In many developing countries and Nigeria in particular, the industrial revolution is premised on the surmise that the process and pattern of development can be accelerated through apposite agricultural policies. Omoruyi (1990) accentuated agriculture as the backbone of the economy in many developing countries including Nigeria and considered growth in agricultural development as capable of impacting enormously on both the rural community and the economy as a whole. Besides, Myrdal (1970:452) earlier maintained the fundamental role of agriculture in development stating that "it is in the agricultural sector that the battle for long term economic development will be won and lost". He also affirmed that the "main burden of development and employment creation will have to be borne by the part of the economy in which agriculture is the predominant activity that is the rural sector',

This is corroborated by the National Planning Commission of Nigeria (2004) in the document National Economic Empowerment and Development Strategy (NEEDS), that agriculture was Nigeria's second largest source of National wealth after oil. Agriculture remains the mainstay of the Nigerian economy despite the dominant role of the petroleum sector as the major foreign exchange earner. In addition to contributing the largest share to the Gross Domestic Product (GDP), it subsists as the largest non-oil export earner. The agricultural industry is the largest employer of labour as a huge percentage of the population derives its income from agriculture and other related activities (Onucheyo, 2001).

Discussing the manner agricultural advancement could promote the economic growth of developing countries, Reynolds (1975) elaborated a four-point blanket which was later expanded by Omoruyi (1990) to five elements expected to be stimulated by agricultural growth:

1. The employment of a substantial proportion of the labour force.

2. The availability of varieties of food for the rapidly increasing population and at affordable prices.

3. The convenience of raw materials which would otherwise have been imported, for the industrial sector.

4. The accessibility of sufficient money in the pockets of farmers so that they can buy needed manufactured input to improve their farming.

5. The provision of support to farmers in order to earn foreign exchange for the importation of much needed industrial equipment.

In direct contrast to this picture, the rate of growth in agricultural production in Nigeria has declined and even stagnated over the decades as it fails to keep pace with its rapidly growing population (from 144 million in 2006 to a roughly estimated 160 million now). The decline in agricultural production has been blamed on petroleum oil discovery and its exploitation. Ukeye (2003) observed that prior to the discovery of oil in Nigeria, agriculture contributed about $64 \%$ to the total GDP immediately after independence, but in the 1970's during the oil boom, the agricultural contribution declined to $48 \%$. The decline continued to $20 \%$ in 1980 and to $19 \%$ in 1985. A sectorial analysis in 2006 of the real GDP indicated that the agricultural sector contributed to about $42 \%$ of the GDP compared with $41.2 \%$ in 2005 (CBN, 2006).

We must recognise the fact that for Nigeria to move forward economically as a nation, it must pay particular attention to its agricultural sector. The state of the Nigerian nation must be tied to its agriculture and not solely to the petroleum sector. It is quite evident that over-dependence on petroleum oil exploitation has been detrimental to the economic growth of Nigeria and the socio-cultural harmony of its peoples. Moreover, especially for reason of the danger it poses environmentally, fossil fuel is no longer fashionable. Recent researches in nuclear, solar, geothermal, bio fuel, etc. indicate that the exploitation of cleaner energy sources is being sufficiently developed to meet most of the World's energy requirements. Though the change may be gradual because of the huge investments required, the time will certainly come when petroleum exploitation will probably be halted. As a nation, we must give thought to the possibility that the oil reserves may one day be exhausted. If that happens, what will be the fate of the country since our oil revenues are not sufficiently being invested on infrastructural development or other sectors of the economy like agriculture?

\section{Theoretical Framework}

The focus of this paper is factored on the framework of Heckscher Ohlins's theory of endowment, which states that a country with relatively abundant stock of skilled labour will have a comparative advantage in producing goods that require relatively large amount of skilled labour. Nigeria with roughly about one hundred and sixty million $(160 \mathrm{~m})$ people and a land size of about 991,000 square kilometres can be said to be naturally endowed. It has an extensive range of ecological zones with a wide variety of climate and socio-economic 
environments and great diversity of agricultural production systems. With the endowment we have in human capital and vast arable lands for cultivation, it would be more cost effective if we concentrate further on agricultural production using the abundant labour available which will be complimented with the application of modern techniques of farming and the use of high yielding varieties of seedlings and other inputs.

\section{Physiocratic Theory}

Physiocracy, a Greek word for "government of nature" is an economic theory developed by the physiocrats, a group of economists who believed that the wealth of a nation was derived solely from the value of "land agriculture" or "land development". Their theories originated in France and were most popular during the second half of the $18^{\text {th }}$ century (Samezo, 2009).

Physiocracy as the first formal school of thought in Economics was founded in France in the $18^{\text {th }}$ century, under Louis XV and Louis XVI, by the agro-physicist François Quesnay (1694-1744). The French economic doctrine of physiocracy ( $\mathrm{d}$ to mercantilism) believes in compliance with the "ordre naturel" (the natural order) and that the wealth of a nation can be enhanced through agriculture rather than trade (Bell, 1967; Herlitz, 1996; Bhatia, 1999). The socio-economic situation in France had reduced the French peasants from being leasers to being salaried workers and employees of the proprietors. The tax policy was inequitable and unjust (Nembrini, Polivka and Bordis, 1985). The nobility and clergy owned about $2 / 3$ of the land and paid no taxes, while peasants were crushed under high land rents in addition to all sorts of levies such as gabelle (salt tax), dime (tithe to the Church), taille (direct tax on income or land), capitation (income tax per head) etc. The farmers also provided varying degrees of obligations, services and payments to the seigneurs (feudal lords) (Georges Rudé, 1988). So they were barely left with any surplus for the improvement of neither land nor their own consumption standard. From being "rentiers" (leasers), they were reduced to being employees (salaried workers) of the "propriétaires" (owners). Trade was equally hindered by all kinds of duties imposed on goods passing the French provinces.

So France and its economy were in a state of stagnation, since the economy did not promote increase in agricultural productivity nor provided for capital accumulation or production capacity. Until 1750, France neglected totally the reinvestment of a portion of its income (rente foncière) into agriculture. This situation was in disparity with what obtained in England during the period, where the increasing usefulness and profitability of agriculture were being enjoyed. The French government settled on the doctrine of Physiocracy because it advanced solutions to the nation's financial crises. It defended the position of French planters and encouraged enhanced agricultural output and exports. André Bourde (1995:488) emphasised the fact that at the period of serious economic difficulties in $18^{\text {th }}$ century France, the French government applied the ideas of Physiocracy to help turn around the agricultural sector of the economy:

C'est alors qu'apparaît l'idée - fondée sur les calculs et les théories de la physiocratie - de prélever l'impôt de quotité sur le "produit net" de l'agriculture, encouragée, améliorée, réinstallée dans un circuit de production et des échanges, mise entre les mains d'une classe de "propriétaires" déféodalisés pour ainsi dire. The idea then occurred - based on the speculations and theories of Physiocracy - to impose the quota tax on the "net product" of agriculture, encouraged improved and reinstated within the circuit of production and exchanges placed in the hands of a class of de-feudalised "proprietors" so to speak. (Translation ours)

It was however with the intension to encourage the farmers and to eliminate arbitrariness in agricultural taxation that the quota tax was introduced.

It is comprehensible that because of the state of extreme socio-political decay of the French monarchy of that period, the success of the input of physiocratic principles into the French economy was not enough to prevent the French Revolution of 1789. However, over succeeding centuries in France, the sustained focus placed on agricultural productivity has caused remarkable improvement in the economy. Robert Prosser (2005: 28) affirmed that:

Almost $60 \%$ per cent of France's land area is used for some

form of agriculture. France is Europe's largest producer of

foodstuffs and provides over 20 per cent of the EU's total output

by valu France has become the largest exporter of food products in the EU. 
The most significant contribution of the physiocrats to economic development was their emphasis on productive work as the source of national wealth. This is in opposition to earlier schools, in particular mercantilism, which focused on trade (mainly exports) resulting in the rulers' wealth accumulation of gold as well as in balance of trade. Physiocrats on the other hand viewed the production of goods and services as consumption of the agricultural surplus, while modern economists considered these to be productive activities which add to national income.

\section{Physiocracy In Practice}

Agriculture is a key contributor to wealth creation and thus significantly promotes poverty alleviation. In line with the physiocratic doctrine of reliance on agriculture as the major source of revenue wealth, many countries of the Third World have adopted predominantly agricultural practices in the development of their economies. Paraguay in South America, for example, has a predominantly agricultural economy. It is on record that in Paraguay more than 250,000 families depend on subsistence farming activities and maintain marginal ties to the larger productive sector of the economy. The Paraguay government welcomes and encourages foreign investment. The economy is dependent on the export of agricultural products such as soya-beans, cotton, grains, cattle, timber, bead, pork, sugarcane, cassava, fruits, vegetables, leather, etc. Agricultural activities of the country, most of which are for export, represent about $16 \%$ of Gross Domestic Product (GDP) and employ about one-quarter of the workforce. The Central Bank of Paraguay (2010) recorded that her real GDP in 2010 of $\$ 17.16$ billion represented an increase of almost $17 \%$ from $\$ 14.68$ billion in 2009. Official foreign exchange reserves rose up from $\$ 2.8$ billion in 2008 to $\$ 3.8$ billion in 2009. Paraguay’s major export markets are Brazil, Uruguay, Chile, Argentina and the United States.

Of relevance to this discourse is the fact that the adoption of the right economic policies by our African nations is the first step to the attainment of the Millennium Development goals (MDGs). But of greater significance is the execution of such policies. Nigeria as a country has had some laudable programmes and policies but the problem has always been on the implementation of such policies. In the past three decades, the Federal government of Nigeria has put different programmes and projects in place, in a bid to set agriculture in its rightful position. Examples of such programmes are shown in Table 1. (See Appendix 1). However, the rate of growth in agricultural production has declined and even stagnated over the decades and it fails to meet the needs of and keep pace with a rapidly growing population of Nigeria (from 144 million in 2006 to a roughly estimated 160 million now).

\section{Physiocracy And Poverty Alleviation In Nigeria}

Before the discovery of petroleum oil, Nigeria's economic progress based on agriculture constituted strides in the right direction of development, since it was able to provide sufficient food and generate income for the country. We are of the opinion that the problem of poverty in Nigeria could be better addressed if the principles of physiocracy were followed appropriately. For example, one way of tackling poverty is through economic empowerment, and this can be achieved through agricultural activities. Employment could also be generated for a large number of people in the society. Poor nutrition could be checked by agriculture through the provision of quality food of various kinds at affordable rates to the entire population. Adegeye and Dittoh (1985) aptly summarised the contribution of agriculture to the Nigerian economy as the provision of adequate and well-balanced food supply, raw materials for our domestic industries, employment opportunities and markets for the industrial sector. They also underlined its contribution to capital formation, funds to GDP and export earnings as well as improvement of the general welfare of the rural people.

The situation in Nigeria calls for urgent attention in view of the level of unemployment, poverty level, poor health sanitation, etc. We observe the engagement of the government in laudable agricultural projects aimed to alleviate poverty in Nigeria. These are however judged to comprise more of paperwork and propaganda than implemented activities. Therefore, since the principles of physiocracy are not fully or properly followed, the government is unable to address the poverty situation in Nigeria. So, the issue here is not about the different programmes of the government, but the genuine implementation of the programmes. This could be verified in table 2 (the percentage share of agriculture to GDP).

\section{Percentage Ratio Of Agricultural Output To Gross Domestic Product In Nigeria (1981-2010)}

Table 2 and chart 1(see appendix 2 and appendix 3) show the percentage share of agricultural output to the Gross Domestic Product (GDP) in Nigeria. The table and chart clearly illustrate a continuous decline from the highest percentage of 48.6 recorded in 2002 and the least 26.0 which was recorded in 2000. The figures show instability or inconsistency. In 1981, the percentage share to GDP was 28.5. The figure increased slightly to $41.6 \%$ in 1988 but there after experienced gradually decline to $33.9 \%$ in 1992 and then to $31.1 \%$ in 1996 , and 
increased again to $39.4 \%$ in 1998 . However, after 2002, the rate continuously declined and in 2010 it stood at $35.2 \%$.

Thus, for agriculture to play the desired role of alleviating poverty in Nigeria, efforts should be made to make the agricultural sector more productive and attractive so that the rate can increase once more to about $60 \%$ - 70\% of the GDP. These efforts should come from the government, individuals and private sector partnership. The improvement will come through good government policies; credit facilities, improved equipments and inputs as well as good market value for agricultural output to encourage the farmers.

\section{Adopting Physiocratic Policies In Poverty Alleviation In Nigeria}

The policy of laissez-faire should be adopted by the Nigerian government. This allows the market forces of demand and supply to determine prices of agricultural outputs. Therefore the farm produce will get the actual value and the producers will get good value for their products through export. The farmers are therefore financially empowered and encouraged to produce more.

\section{Agriculture And Net Product:}

One major emphasis of the physiocratic policies was the relevance and reliance on agriculture for wealth generation. Net product or surplus is made possible when labour is applied to land. So the interest in agriculture needs to be rekindled to regain the lost glory, and to diversify the economy. Through agriculture, more people will be gainfully employed in the rural areas and more income also generated. This will help to improve on their nutrition in addition to their financial status. This again is capable of reducing poverty.

\section{Taxation:}

The Physiocrats believe that the surplus or the net product be taxed equitably. This type of tax does not create or increase the burdens on the payer or appears as a loss to the tax payer. The government expenditure should be within the tax revenue collected. This type of tax could be considered as convenience, equitable, and economic. Such tax that is imposed on net product (surplus) will ensure that the source of the nation's wealth is preserved. The tax payers are also better encouraged to produce more in order to generate more income which will translate to more income with which they (farmers) can solve their financial problems. There will be an end to taxes that are contingent on production, labour and trade. They would nurture capital which is distinguished from land.

\section{Capital in Production.}

The physiocrats gave a lot of thought to the role of capital in production. They saw capital in form of advances and stressed the importance of getting it back. The revenue generated is reinvested to create new incomes and the quicker the time of repayment the better. This could be likened to the policy of micro credit scheme and credits given to farmers through co-operative societies, micro finance banks etc. Proper utilisation of such credit is very important. Therefore monitoring and supervision of the beneficiaries will help to achieve the desired result.

\section{Recommendations And Conclusion}

This paper plainly indicated that with Nigeria's present over-dependence on petroleum oil, the balance of payment equilibrium is not attainable since oil prices cannot continue to rise indefinitely and increases in the OPEC quota are not guaranteed. So, aggressive export expansion and diversification away from oil as well as gradual import liberalisation, represent the winning strategies for forging ahead. Worthy of emulation are the examples of other third world economies such as Paraguay and of course Bangladesh which is a world major rice producer and has her agricultural product accounting for about 30\% of the nation's GDP.'s economy.

Consequently, we hold that in Nigeria, all efforts to reduce crime, create employment and maintain good health as well as alleviate poverty would continue to confront futility except concentration is placed on the agricultural sector more than ever before. We therefore make the following recommendations:

i. The government should create an enabling environment for agriculture to survive through soft loans with low interest rates to farmers. The government through good policies should make it possible for farmers to easily assess credit and to take the advantage of the assistance of available international funds schemes such as Food and Agricultural Organization (FAO).

ii. Our good weather should be harnessed in order to have farming all year-round; as such even in dry season through irrigation, farming of adaptable crops can take place.

iii. Agriculture can create gainful employment for a large number of the population and through such employment poverty among the people can be alleviated. 
iv. Apart from income generation, it makes food available thereby improving the nutrition and health standards of the citizens. Therefore, the government should make available improved varieties and high yielding seedlings to the farmers at subsidised rates.

v. For the farmers to be encouraged there should be both local and international markets to sell their products where they can get actual value for their effort in terms of profit.

vi. To reduce occurring waste during harvest seasons, adequate storage facilities should be provided. Besides the government should encourage investment in food-processing factories (fruit juice factory) to accommodate surplus agricultural produce neither immediately consumable nor able to be preserved for a very long period should be processed and canned for future consumption.

vii. The government should make effort to add value to the nation's exportables through processing (instead of exporting them in their raw state) so that they can attract more revenue.

viii. All this implies that a great percentage of the revenue accruing from the petroleum sector should be advanced into the agricultural sector and encouragement given to rich individuals and private sectors to massively invest in large-scale and mechanised farming.

\section{References}

[1]. Adegeye, A. J. \& Ditloh, J. S. (1985). Essentials of Agricultural Economics. Impact Publishers. Ltd.:Ibadan.

[2]. Anyanwu, J. C., Oyefusi, S. A., Oaikhena, H. \& Dimowo, F.G. (1997). The Structure of the Nigerian Economy (1960-1997), Joance Educational Publishers: Onitsha.

[3]. Bell, R. (1967). History of Economic Thought. The Ronald Press Company: New York.

[4]. Bhatia, H. L. (1999). History of Economic Thought. Vikas Publishing House PVT Ltd.: New Delhi.

[5]. Bourde, André (1995). "Les 'Lumières', 1715 - 1789'. Duby, Georges (ed). Histoire de la France des origines à nos jours. Larousse : Paris. $476-515$.

[6]. Cantillon, Richard (1949). Essay on the Nature of Commerce in general. Henry H. (1999) (Ed). Frank Cass and Co. Ltd.: London

[7]. Denzar, L. \& Guyer, J. I. (2005), Vision and Policy in Nigerian Economics: The Legacy of Pius Okigbo, Ibadan University: Press Ibadan.

[8]. Greenlaw, R. W. (1975). The Social Origins of the French Revolution, Massachusetts: D. C. Health and Company.

[9]. Herlitz, Lars (1996). "From Spending and Reproduction to Circuit Flow and Equilibrium: the Two Conceptions of Tableau Économique". The European Journal of the History of Economic Thought, 1469-5936, (3)1, 1 - 20.

[10]. Myrdal, Gunnar (1970). « The Challenge of World Poverty ». Pantheon: New York. 30-31

[11]. National Planning Commission (2004). Economic Empowerment and Development Strategy (NEEDS). Central Bank of Nigeria (2005 reprint): Abuja.

[12]. Nembrini, J. L, Polivka, P. \& Bordis, J. (1985). Histoire CM. «Collection Pour Connaître la France ». Hachette : Paris

[13]. Omoruyi, S.A (1990). Prescribed Agricultural Science. Idodo Umeh Publisher Ltd.: Benin.

[14]. Powel, R. (1991). Economics for Professional and Business Studies. Dp Publication Ltd.: London.

[15]. Prosser. Robert (2005). Countries of the World: France. Evans Brothers Ltd: London

[16]. Reynolds, L.G. (1975). Agriculture in Development Theory. Yale University Press : London.

[17]. Rudé, George (1988). The French Revolution: its Causes, its History and its Legacy after 200 Years. Grove Press : New York.

[18]. Todaro, M.P. \& Smith, S.C. (2005). Economic Development. Pearson Education Ltd. : India.

[19]. Viner, Jacob (1937). Studies in the Theory of International Trade. Harper and Row: New York.

\section{Appendix 1}

Table1: Agricultural Development Programmes In Nigeria

\begin{tabular}{|c|c|c|c|}
\hline S/No & YEARS & PROGRAMMES & NATURE OF ACTIVITY \\
\hline 1 & 1975 & Agricultural Development Programme (ADP) & $\begin{array}{l}\text { Provision of decentralized opportunities and resources in } \\
\text { agriculture to small holder farmers }\end{array}$ \\
\hline 2 & 1976 & Operation Feed the Nation (OFN) & $\begin{array}{l}\text { To provide sufficient food for all Nigerians. } \\
\text { To facilitate agricultural credit for commercial banks to } \\
\text { farmers }\end{array}$ \\
\hline 3 & 1976 & River Basic Development Authority & $\begin{array}{l}\text { To undertake comprehensive development of both surface } \\
\text { and underground resources for various purpose (e.g. } \\
\text { provision or irrigation, infrastructure, and control of flood, } \\
\text { soil erosion and watershed management). }\end{array}$ \\
\hline 4 & 1976 & Green Revolution & To provide sufficient food for all Nigerians. \\
\hline 5 & 1986 & $\begin{array}{lllll}\text { Directorate of Foods, } & \text { Roads } & \text { and } & \text { Rural } \\
\text { infrastructure (DFRRI) } & & & \end{array}$ & $\begin{array}{l}\text { To coordinate and streamline all rural development } \\
\text { activities in the country and to accelerate the pace of } \\
\text { integrated rural development. }\end{array}$ \\
\hline 6 & 1986 & National Directorate of employment. & $\begin{array}{l}\text { To provide skill development to secondary school levers } \\
\text { and graduates from tertiary institution }\end{array}$ \\
\hline 7 & 1987 & Nigerian agricultural insurance cooperation. & $\begin{array}{l}\text { Provision for insurance cover for business engaged in } \\
\text { agricultural development production. }\end{array}$ \\
\hline 8 & 1987 & Better life for rural women. & Improvement of living conditions of rural women. \\
\hline 9 & 1988 & Strategic Grains reserve (SGR). & $\begin{array}{l}\text { To mop up access grain production and make such } \\
\text { available locally in times of scarcity. }\end{array}$ \\
\hline 10 & 1992 & $\begin{array}{llll}\text { Family } & \text { Economic } & \text { Advancement } & \text { Programme } \\
\text { (FEAP). } & & & \end{array}$ & $\begin{array}{l}\text { Provision of access of credit for micro entrepreneurs at the } \\
\text { grassroots levels; encouragement of job creation, local raw } \\
\text { materials utilization, and development of indigenous } \\
\text { technology. }\end{array}$ \\
\hline 11 & 1994 & Family Support Programme. & To promote the welfare of women and children. \\
\hline
\end{tabular}


Attaining Poverty Alleviation Through Physiocratic Principles: Nigeria In Focus

\begin{tabular}{|l|l|l|l|}
\hline 12 & 2000 & National poverty eradication programme. & $\begin{array}{l}\text { To coordinate implementation of all FGN poverty } \\
\text { eradicated programs. }\end{array}$ \\
\hline 13 & 2000 & $\begin{array}{l}\text { Nigeria agricultural cooperation and rural } \\
\text { development bank. }\end{array}$ & $\begin{array}{l}\text { Provision of credits for the production, processing and } \\
\text { marketing of agricultural products }\end{array}$ \\
\hline 14 & 2000 & Forestry development programme. & $\begin{array}{l}\text { Provision of trees seedlings and other forestry } \\
\text { development facilities to local community participating in } \\
\text { the countries five ecological zones. }\end{array}$ \\
\hline
\end{tabular}

Source: National Economic Empowerment and Development Strategy NEEDS

Appendix 2

Table 2: Percentage Share of Agricultural Output on GDP

\begin{tabular}{|l|l|l|l|}
\hline YEAR & AGRIC & GDP & $\begin{array}{l}\text { PERCENTAGE SHARE (\%) } \\
\text { OF AGRIC ON GDP }\end{array}$ \\
\hline 1981 & $13,580.32$ & $47,619.66$ & $28.5 \%$ \\
\hline 1982 & $15,905.50$ & $49,069.28$ & $32.4 \%$ \\
\hline 1983 & $18,837,19$ & $53,107.38$ & $35.5 \%$ \\
\hline 1984 & $23,799.43$ & $59,622.53$ & $39.9 \%$ \\
\hline 1985 & $26,625.21$ & $67,908.55$ & $39.2 \%$ \\
\hline 1986 & $27,887.45$ & $69,146.99$ & $40.3 \%$ \\
\hline 1987 & $39,204.22$ & $105,222.84$ & $37.3 \%$ \\
\hline 1988 & $57,924.34$ & $139,085.30$ & $41.6 \%$ \\
\hline 1989 & $69,711.00$ & $216,797.54$ & $32.2 \%$ \\
\hline 1990 & $84,344.61$ & $264,548.99$ & $31.5 \%$ \\
\hline 1991 & $97,464.06$ & $312,139.74$ & $31.2 \%$ \\
\hline 1992 & $145,225.25$ & $532,613.83$ & $27.3 \%$ \\
\hline 1993 & $231,832.67$ & $683,869.79$ & $33.9 \%$ \\
\hline 1994 & $349,244.86$ & $899,863.22$ & $38.8 \%$ \\
\hline 1995 & $619,806.83$ & $1,933,211.55$ & $32,1 \%$ \\
\hline 1996 & $841,457.07$ & $2,702,719.13$ & $31.1 \%$ \\
\hline 1997 & $953,549.37$ & $2,801,972.58$ & $34.0 \%$ \\
\hline 1998 & $1,057,584.01$ & $2,708,430.86$ & $39.0 \%$ \\
\hline 1999 & $1,127,693.12$ & $3,194,014.97$ & $35.3 \%$ \\
\hline 2000 & $1,192,910.00$ & $4,582,127.29$ & $26.0 \%$ \\
\hline 2001 & $1,594,895.53$ & $4,725,086.00$ & $33.8 \%$ \\
\hline 2002 & $3,357,062.94$ & $6,912,381.25$ & $48.6 \%$ \\
\hline 2003 & $3,624,579.49$ & $8,487,031.57$ & $42.7 \%$ \\
\hline 2004 & $3,903,758.69$ & $11,411,066.91$ & $34.2 \%$ \\
\hline 2005 & $4,773,198.38$ & $14,572,239.12$ & $32.8 \%$ \\
\hline 2006 & $5,940,236.97$ & $18,564,594.73$ & $32,0 \%$ \\
\hline 2007 & $6,757,867.73$ & $20,657,317.67$ & $32.7 \%$ \\
\hline 2008 & $7,981,397.32$ & $24,296,329.29$ & $32.9 \%$ \\
\hline 2009 & $9,186,306.05$ & $24,794,238.66$ & $37.1 \%$ \\
\hline 2010 & $10,273,651.99$ & $29,205,782.96$ & $35.2 \%$ \\
\hline & & & \\
\hline
\end{tabular}

Source: Central Bank of Nigeria Statistical Bulletin Various issues

Appendix 3

Chart 1

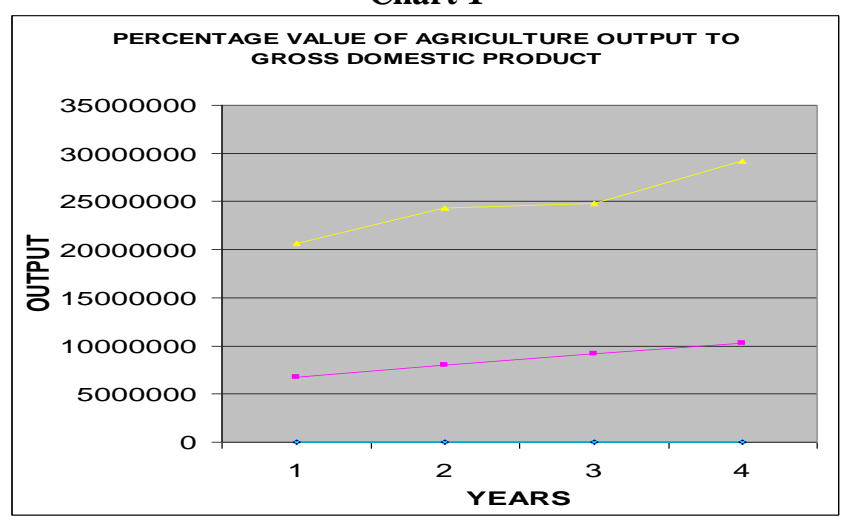

